\title{
MEASUREMENT AND CORRELATION OF HIGH PRESSURE VAPOR-LIQUID EQUILIBRIA FOR THE SYSTEMS ETHYLENE-1-BUTENE AND ETHYLENE-PROPYLENE
}

\author{
HYO KWANG BAE, KUNIO NAGAHAMA \\ AND Mitsuho HIRATA \\ Department of Industrial Chemistry, \\ Tokyo Metropolitan University, Tokyo 158
}

\begin{abstract}
An apparatus is newly designed and constructed for investigation of high-pressure vapor-liquid equilibrium in the temperature range $-50^{\circ} \mathrm{C}$ to $50^{\circ} \mathrm{C}$ at pressures up to $100 \mathrm{~atm}$.

The visual type of static apparatus is distinguished by the inclusion of a specially designed sampling device for liquid phase to reduce experimental error during the sampling, and of a magnetically driven agitator by which the vapor phase is dispersed into the liquid phase within the cell.

Using this apparatus, the binary vapor-liquid equilibrium data for the ethylene-propylene system at $-10.08^{\circ}, 0.07^{\circ}, 10.07^{\circ}$ and $20.14^{\circ} \mathrm{C}$, and ethylene-1-butene at $-0.01^{\circ}, 10.01^{\circ}$ and $20.20^{\circ} \mathrm{C}$ are measured. The data obtained are correlated by using three equations of state. The predicted results are in good agreement with the experimental data except in the region close to the critical point.
\end{abstract}

\section{Introduction}

Reliable vapor-liquid equilibrium data are constantly in demand for the design and the operation of distillation equipment. Many different types of apparatus have been proposed for the measurement of high-pressure vapor-liquid equilibria.

Following the recent development of highly accurate methods of measuring temperature and pressure, the accuracy of high-pressure vapor-liquid data is solely dependent upon obtaining truly equilibrium samples from both phases.

Of the problems encountered in the usual sampling methods, the most troublesome are the disturbance of the equilibrium condition and the condensation of heavier components or the vaporization of lighter components when withdrawing samples from equilibrium apparatus.

This paper describes a new phase equilibrium apparatus, the heart of which is a glass-windowed cell containing a specially designed liquid sampling device and a magnetically driven impeller designed to continuously disperse a vapor phase into an underlying liquid phase. The visibility afforded by the large glass windows of the cell is useful in the detection of liquid or solid phases, dew and bubble points, and critical points.

Received July 15, 1980. Correspondence concerning this article should be addressed to $M$. Hirata.
To verify the capabilities of this apparatus, isothermal high-pressure vapor-liquid equilibrium data have been measured for two binary systems: ethylenepropylene and ethylene-1-butene.

Several dew- and bubble-point data for the ethylenepropylene system were given for a limited range of composition and temperature by Haselden and coworkers ${ }^{2}$.

No vapor-liquid equilibrium data for ethylene-1butene have been reported in the literature.

The measured data have been correlated using several equations of state for testing the capabilities of equations in the region close to the critical.

\section{Apparatus}

The apparatus described here was designed to permit the determination of phase equilibrium in the temperature range from $-50^{\circ}$ to $50^{\circ} \mathrm{C}$ at pressures to $100 \mathrm{~atm}$. It consists of an equilibrium cell with large glass windows, a sampling device for liquid phase and associated equipment for measurements of temperature and pressure. A schematic diagram of the apparatus is shown in Fig. $\mathbf{1}$ and the main units are described in detail as follows.

\section{1 Equilibrium cell}

The cross-sectional view of the equilibrium cell is shown in Fig. 2. The constant-volume cell was constructed from 304 stainless steel and had an internal volume of about $300 \mathrm{~cm}^{3}$. The cell was provided 


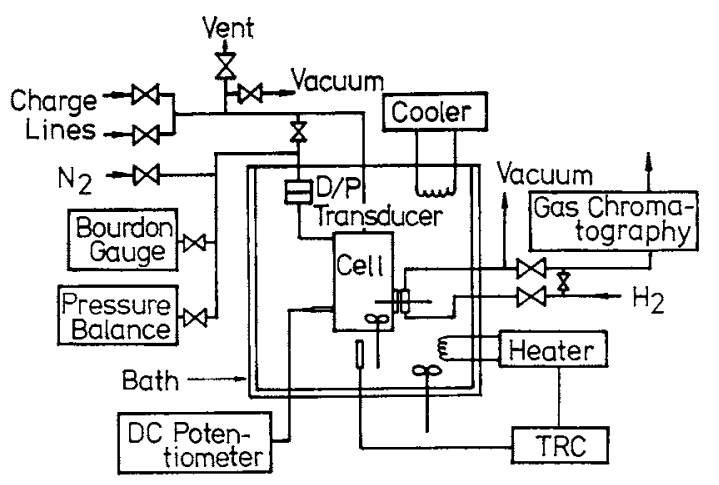

Fig. 1 Schematic flow diagram of experimental apparatus

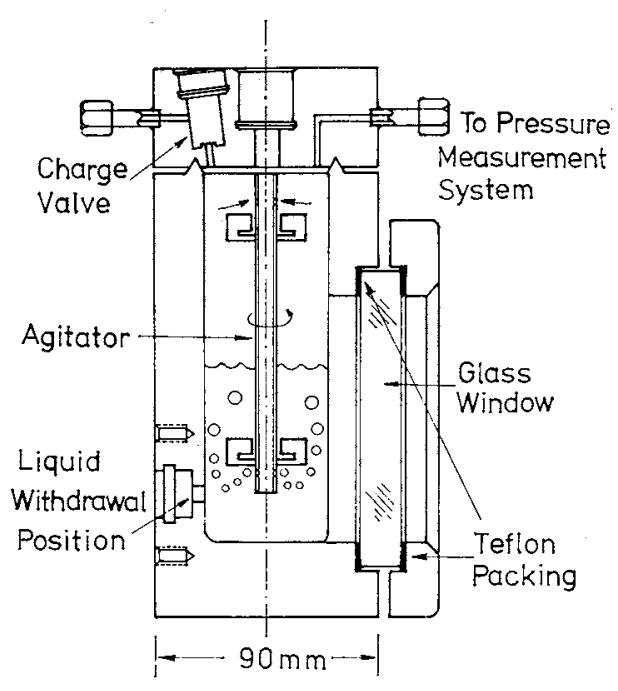

Fig. 2 Equilibrium cell and agitator

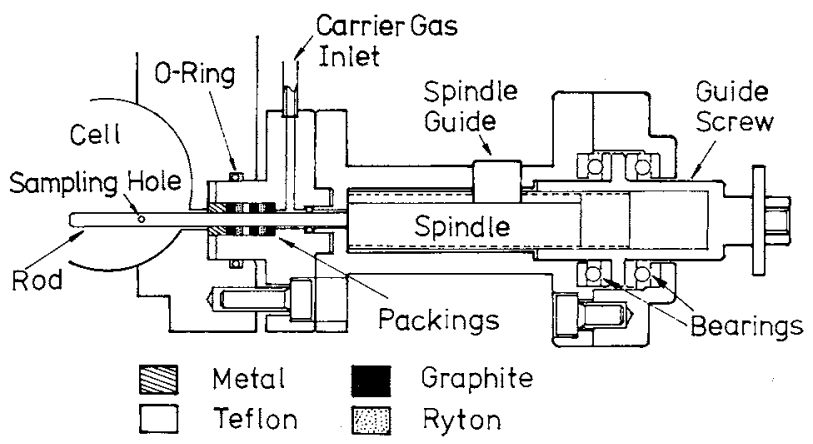

Fig. 3 Liquid sampling device

with two $17 \mathrm{~mm}$-thick reinforced glass windows to allow observation of the position of the interface between phases. Teflon sheet packing was inserted between the glass window and its cover plate.

Mixing in the equilibrium cell was achieved by an internally vaned metallic impeller mounted on a hollow shaft. The agitator was driven by the magnetic couple between external and internal driving magnets. Slocum ${ }^{11}$ employed a similar agitator for a multipurpose phase equilibrium apparatus. Vapor enters the small upper holes, descends the hollow shaft, and flows out through the lower holes to disperse into the liquid phase. The vapor bubbles are continuously drawn into the liquid phase at any condition, reducing the time required to attain equilibrium.

The liquid in the equilibrium cell was sampled through a specially designed device mounted directly into the wall of the cell. The detailed design of the liquid-sampling device is shown in Fig. 3. The design of the device was based on the methods used by Fredenslund et al. ${ }^{11}$ and by $\mathrm{Ng}$ and Robinson ${ }^{81}$. As shown in Fig. 3, it consisted of a $5 \mathrm{~mm}$-diameter stainless steel rod mounted through packings along a radius of the cell. When a liquid sample was desired, the rod, containing a hole of approximately $0.008 \mathrm{~cm}^{3}$, was inserted into the liquid phase and was then pulled outwards without rotating the piston rod, so that the trapped sample was flashed directly into the carrier gas stream of the gas chromatograph.

The packing gland around the sampling piston consisted of graphite, Teflon and Ryton, as shown in Fig. 3.

At the begining, we tried to employ the same device as shown in Fig. 3 for sampling a vapor phase, but serious defect appeared in the determination of composition for the vapor phase. The difficulty arose from the fact that because of agitation and possibly for other reasons, a thin film or small drops of liquid adhered to the wall surface in the vapor space. This caused the empty sampling hole to trap the liquid sample instead of the vapor sample when inserted into the vapor phase. Therefore, the vapor sampling technique was changed to the release of a small portion of the vapor into an evacuated collection device.

The equilibrium cell was placed in a constanttemperature bath (approximately $0.12 \mathrm{~m}^{3}$ ) containing liquid ethanol as a coolant. The annular space of the bath was evacuated to prevent heat transfer from the surroundings. The usual method of temperature control was adopted by a combination of Neslab cooler and heat input using a electrical resistance heater. The deviation from the desired temperature was detected using a calibrated platinum resistance thermometer and was used as the input to a PID controller, which in turn regulated the amount of heat added to the heater. In this way, it was possible to control the bath temperature within $0.03 \mathrm{~K}$ by thoroughly stirring the bath fluid by a powerful agitator.

\subsection{Temperature and pressure measurement}

The bath temperature surrounding the equilibrium cell was measured by a calibrated platinum resistance thermometer. It was assumed that this temperature was the same as that inside the cell. The resistance of the thermometer was measured by connecting it in series with a standard resistance and comparing the 
voltage drops across them by means of a Yokogawa Model 2723 DC potentiometer. The probable error in temperature measurement was $\pm 0.05 \mathrm{~K}$ around the temperature of interest.

A schematic diagram of pressure measurement is shown in Fig. 4. From the vapor space in the cell, the pressure is transmitted to the nitrogen surge tank by means of a specially designed differential pressure transducer immersed in the bath fluid. Through nitrogen gas the pressure is transmitted via a gas-oil separator to the oil system containing an Aminco pressure balance. Determination of the pressure in the system was done by adjusting the null position of the bellows, which was indicated with a displacement meter.

A mercury manometer rather than a pressure balance was used for pressures lower than $0.38 \mathrm{MPa}$. The accuracy of pressure measurement was within $\pm 274 \mathrm{~Pa}$ for the pressure balance and $\pm 67 \mathrm{~Pa}$ for the manometer.

\section{Experiments}

Research-grade pure components were supplied by Takachiho Chemical Industry Co. The ethylene, propylene and 1-butene had a specified purity of at least $99.9 \%$.

At the start of a run, the cell was adequately evacuated and a sufficient amount of mixture was added to ensure that the liquid sampling rod was completely immersed in the liquid phase. Vapor recirculation inside the equilibrium cell was carried out by operating an internally vaned impeller mounted on a hollow shaft.

After the system was allowed to remain at desired temperature and at constant pressure for at least two hours, liquid samples were trapped in a small hole for direct analysis of liquid composition, and then a small portion of the vapor was released to the evacuated vesset.

A Simazu Model GC-3AH gas chromatograph with a Simazu Model ITG-1 A digital integrator was used for composition analysis, employing hydrogen as a carrier gas.

A $6 \mathrm{~m}$ by $3 \mathrm{~mm}$-diameter column packed with Sebaconitrile/Chromosorb $\mathrm{P}$ was used at $50^{\circ} \mathrm{C}$. The gas chromatograph was calibrated using about ten calibration mixtures prepared by weighting each component into an evacuated $1000-\mathrm{cm}^{3}$ heavy-wall glass bottle. The reproducibility of the analysis was typically within 0.2 mole $\%$. At least three analyses were done on each sample.

\section{Result and Discussion}

Isothermal vapor-liquid equilibrium data were obtained for the ethylene-propylene system at $-10.08^{\circ}$,

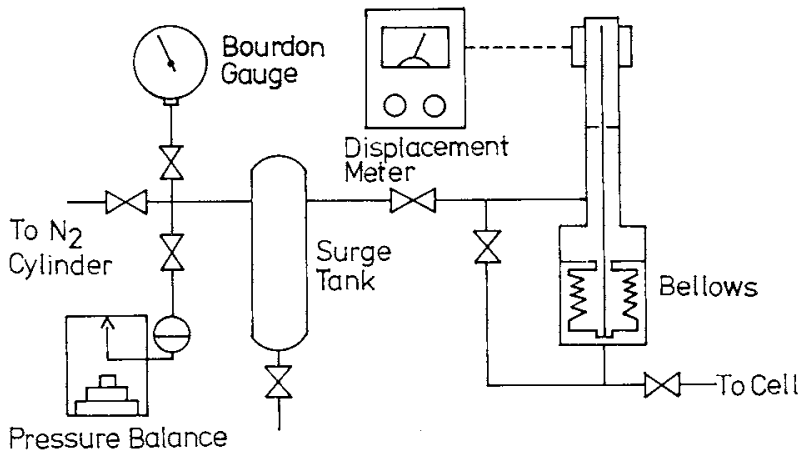

Fig. 4 Schematic diagram of pressure measurement system

$0.07^{\circ}, 10.07^{\circ}$ and $20.14^{\circ} \mathrm{C}$, and for the ethylene-1butene system at $-0.01^{\circ}, 10.01^{\circ}$ and $20.20^{\circ} \mathrm{C}$. The observed results are given in Tables $\mathbf{1}$ and $\mathbf{2}$, and shown graphically in Figs. 5 and $\mathbf{6}$. The logarithmic plot of equilibrium constant against total pressure is shown in Figs. 7 and 8.

The vapor-liquid equilibrium data for the ethylene1-butene system are not available in the literature up to the present. Several dew and bubble point data for the ethylene-propylene system were previously reported by Haselden et al. ${ }^{2}$. The datum point at $0^{\circ} \mathrm{C}$ agrees well with the present result, as shown in Fig. 5. The solid lines in Figs. 5, 6, 7 and 8 represent the values predicted by the modified Redlich-Kwong equations of state proposed by Joffe et al. ${ }^{4)}$, Soave ${ }^{12)}$ and Peng and Robinson ${ }^{10)}$.

For each isotherm, only a single line is indicated in Figs. 5 to 8 because the calculated results from the three equations of state are nearly identical.

Three equations of state and the mixing rule for mixture are summarized in Appendix. No description is made here of the utilization of the equations in calculating vapor-liquid equilibrium since this was earlier described elsewhere ${ }^{6,9,10,12,13}$. The computational method in this work is identical to that proposed by Hirata et $a l .^{3)}$ and Nagahama et al. ${ }^{7}$. The binary interaction parameter, $\theta_{i j}$, to be employed in the mixing rule is determined by fitting it to all the experimental data points of pressure and liquid composition. The determined values are listed in Table 3, together with the deviations between the observed and calculated vapor composition or pressure. Although somewhat large deviations are shown in the region near the critical point, the experimental data are, on the whole, in good agreement with the calculated results.

For some isotherms, the critical pressures and compositions of mixture are determined by extrapolation of the data near the critical point, which is identical to the method of Muirbrook and Prausnit $z^{5}$. The critical properties in this study are shown in Table 4. To investigate the internal consistency of the experi- 


\begin{tabular}{|c|c|c|c|c|}
\hline$P[\mathrm{~atm}]$ & $x_{1}$ & $y_{1}$ & $K_{1}$ & $K_{2}$ \\
\hline \multicolumn{5}{|c|}{ Temperature $=-10.08^{\circ} \mathrm{C}$} \\
\hline 4.183 & 0.0 & 0.0 & - & 1.0 \\
\hline 6.46 & 0.094 & 0.382 & 4.064 & 0.682 \\
\hline 8.00 & 0.159 & 0.522 & 3.283 & 0.568 \\
\hline 11.96 & 0.313 & 0.710 & 2.268 & 0.422 \\
\hline 14.82 & 0.433 & 0.792 & 1.829 & 0.367 \\
\hline 17.04 & 0.507 & 0.836 & 1.649 & 0.333 \\
\hline 20.40 & 0.625 & 0.884 & 1.414 & 0.309 \\
\hline 23.25 & 0.740 & 0.918 & 1.241 & 0.315 \\
\hline 26.36 & 0.840 & 0.947 & 1.127 & 0.331 \\
\hline 29.28 & 0.928 & 0.973 & 1.048 & 0.375 \\
\hline 31.89 & 1.0 & 1.0 & 1.0 & - \\
\hline \multicolumn{5}{|c|}{ Temperature $=0.07^{\circ} \mathrm{C}$} \\
\hline 5.817 & 0.0 & 0.0 & - & 1.0 \\
\hline 7.86 & 0.066 & 0.292 & 4.424 & 0.758 \\
\hline 10.19 & 0.150 & 0.466 & 3.107 & 0.628 \\
\hline 12.90 & 0.234 & 0.606 & 2.590 & 0.514 \\
\hline 16.70 & 0.356 & 0.718 & 2.017 & 0.438 \\
\hline 20.63 & 0.488 & 0.797 & 1.633 & 0.396 \\
\hline 24.86 & 0.610 & 0.856 & 1.403 & 0.369 \\
\hline 29.51 & 0.730 & 0.905 & 1.240 & 0.352 \\
\hline 32.51 & 0.818 & 0.933 & 1.141 & 0.368 \\
\hline 35.25 & 0.876 & 0.955 & 1.090 & 0.363 \\
\hline 40.430 & 1.0 & 1.0 & 1.0 & - \\
\hline \multicolumn{5}{|c|}{ Temperature $=10.07^{\circ} \mathrm{C}$} \\
\hline 7.741 & 0.0 & 0.0 & - & 1.0 \\
\hline 10.22 & 0.057 & 0.269 & 4.719 & 0.775 \\
\hline 11.87 & 0.116 & 0.383 & 3.302 & 0.698 \\
\hline 16.30 & 0.242 & 0.571 & 2.360 & 0.566 \\
\hline 21.34 & 0.383 & 0.702 & 1.833 & 0.483 \\
\hline 26.18 & 0.511 & 0.785 & 1.536 & 0.440 \\
\hline 30.31 & 0.613 & 0.830 & 1.354 & 0.439 \\
\hline 34.63 & 0.705 & 0.871 & 1.235 & 0.437 \\
\hline 40.34 & 0.822 & 0.921 & 1.120 & 0.444 \\
\hline 43.90 & 0.888 & 0.946 & 1.065 & 0.482 \\
\hline 45.81 & 0.916 & 0.960 & 1.048 & 0.476 \\
\hline 49.18 & 0.972 & 0.984 & 1.012 & 0.571 \\
\hline 50.06 & 0.984 & 0.989 & 1.005 & 0.688 \\
\hline \multicolumn{5}{|c|}{ Temperature $=20.14^{\circ} \mathrm{C}$} \\
\hline 10.130 & 0.0 & 0.0 & - & 1.0 \\
\hline 14.18 & 0.106 & 0.313 & 2.953 & 0.768 \\
\hline 17.72 & 0.188 & 0.463 & 2.463 & 0.661 \\
\hline 23.94 & 0.338 & 0.629 & 1.861 & 0.560 \\
\hline 28.50 & 0.440 & 0.706 & 1.605 & 0.525 \\
\hline 33.85 & 0.554 & 0.774 & 1.397 & 0.507 \\
\hline 39.77 & 0.671 & 0.832 & 1.240 & 0.511 \\
\hline 45.92 & 0.782 & 0.877 & 1.121 & 0.564 \\
\hline 49.21 & 0.835 & 0.901 & 1.079 & 0.600 \\
\hline 49.68 & 0.839 & 0.901 & 1.074 & 0.615 \\
\hline 52.27 & 0.877 & 0.910 & 1.038 & 0.732 \\
\hline 52.69 & 0.907 & 0.911 & 1.004 & 0.957 \\
\hline
\end{tabular}

mental data for both phases at low concentration of ethylene, the relations of pressure vs. liquid composition and those of pressure vs. enhancement factor $\left(P y_{2} / P_{2}^{s}\right)$ were plotted. For liquid phase, a plot of $\left(P-P_{2}^{s}\right)$ against liquid mole fraction of ethylene extrapolated smoothly to the origin as the mole fraction of ethylene approached zero. In addition, in the region of very low ethylene concentration a linear relation was obtained. For the vapor phase, a plot of enhancement factor vs. $\left(P-P_{2}^{s}\right)$ formed a smooth curve extrapolating to unity. The individual curves
Table 2 Vapor-liquid equilibrium data for the system ethylene (1)-1-butene (2)

\begin{tabular}{|c|c|c|c|c|}
\hline$P[\mathrm{~atm}]$ & $x_{1}$ & $y_{1}$ & $K_{1}$ & $K_{2}$ \\
\hline \multicolumn{5}{|c|}{ Temperature $=-0.01^{\circ} \mathrm{C}$} \\
\hline 1.263 & 0.0 & 0.0 & - & 1.0 \\
\hline 2.027 & 0.023 & 0.382 & 16.609 & 0.633 \\
\hline 2.176 & 0.030 & 0.433 & 14.433 & 0.584 \\
\hline 3.66 & 0.101 & 0.676 & 6.693 & 0.360 \\
\hline 6.10 & 0.188 & 0.803 & 4.271 & 0.243 \\
\hline 8.21 & 0.261 & 0.857 & 3.284 & 0.194 \\
\hline 10.97 & 0.341 & 0.896 & 2.628 & 0.158 \\
\hline 15.28 & 0.457 & 0.928 & 2.031 & 0.133 \\
\hline 19.19 & 0.536 & 0.946 & 1.765 & 0.116 \\
\hline 19.55 & 0.571 & 0.946 & 1.657 & 0.126 \\
\hline 22.78 & 0.649 & 0.956 & 1.473 & 0.125 \\
\hline 24.73 & 0.681 & 0.962 & 1.413 & 0.119 \\
\hline 24.73 & 0.698 & 0.963 & 1.380 & 0.123 \\
\hline 27.15 & 0.756 & 0.968 & 1.280 & 0.131 \\
\hline 30.03 & 0.794 & 0.975 & 1.228 & 0.121 \\
\hline 29.95 & 0.816 & 0.975 & 1.195 & 0.136 \\
\hline 33.12 & 0.889 & 0.982 & 1.105 & 0.162 \\
\hline 35.88 & 0.930 & 0.987 & 1.061 & 0.186 \\
\hline 37.89 & 0.961 & 0.998 & 1.039 & 0.051 \\
\hline 40.425 & 1.0 & 1.0 & 1.0 & - \\
\hline \multicolumn{5}{|c|}{ Temperature $=10.01^{\circ} \mathrm{C}$} \\
\hline 1.811 & 0.0 & 0.0 & - & 1.0 \\
\hline 5.19 & 0.083 & 0.663 & 7.988 & 0.368 \\
\hline 9.96 & 0.204 & 0.823 & 4.034 & 0.222 \\
\hline 16.52 & 0.365 & 0.898 & 2.406 & 0.161 \\
\hline 22.21 & 0.504 & 0.927 & 1.839 & 0.147 \\
\hline 29.80 & 0.671 & 0.949 & 1.414 & 0.155 \\
\hline 36.82 & 0.800 & 0.965 & 1.206 & 0.175 \\
\hline 42.37 & 0.889 & 0.977 & 1.099 & 0.207 \\
\hline 46.14 & 0.941 & 0.985 & 1.047 & 0.254 \\
\hline 46.72 & 0.948 & 0.987 & 1.041 & 0.250 \\
\hline 47.80 & 0.960 & 0.989 & 1.030 & 0.275 \\
\hline \multicolumn{5}{|c|}{ Temperature $=20.20^{\circ} \mathrm{C}$} \\
\hline 2.551 & 0.0 & 0.0 & - & 1.0 \\
\hline 4.83 & 0.049 & 0.480 & 9.796 & 0.547 \\
\hline 9.28 & 0.140 & 0.730 & 5.214 & 0.314 \\
\hline 12.54 & 0.211 & 0.800 & 3.791 & 0.253 \\
\hline 19.12 & 0.352 & 0.871 & 2.474 & 0.199 \\
\hline 25.40 & 0.481 & 0.903 & 1.877 & 0.187 \\
\hline 32.00 & 0.607 & 0.928 & 1.529 & 0.183 \\
\hline 34.71 & 0.654 & 0.935 & 1.430 & 0.188 \\
\hline 38.64 & 0.722 & 0.943 & 1.306 & 0.205 \\
\hline 40.99 & 0.758 & 0.948 & 1.251 & 0.215 \\
\hline 45.36 & 0.822 & 0.955 & 1.162 & 0.253 \\
\hline 46.91 & 0.845 & 0.958 & 1.133 & 0.271 \\
\hline 52.04 & 0.904 & 0.967 & 1.070 & 0.344 \\
\hline 53.17 & 0.918 & 0.967 & 1.053 & 0.402 \\
\hline 54.26 & 0.931 & 0.966 & 1.038 & 0.493 \\
\hline
\end{tabular}

demonstrated good internal consistency of the experimental data around low concentration of ethylene.

\section{Conclusions}

Three isotherms of the ethylene-1-butene system and four of the ethylene-propylene system are measured by the new apparatus. This apparatus is characterized by its method of vapor-phase circulation and by its method of sampling liquid phase without disturbing the equilibrium. For the observed data, the simple consistency methods are applied to both vapor and liquid composition at low concentration of ethylene. The consistency test results confirm the 


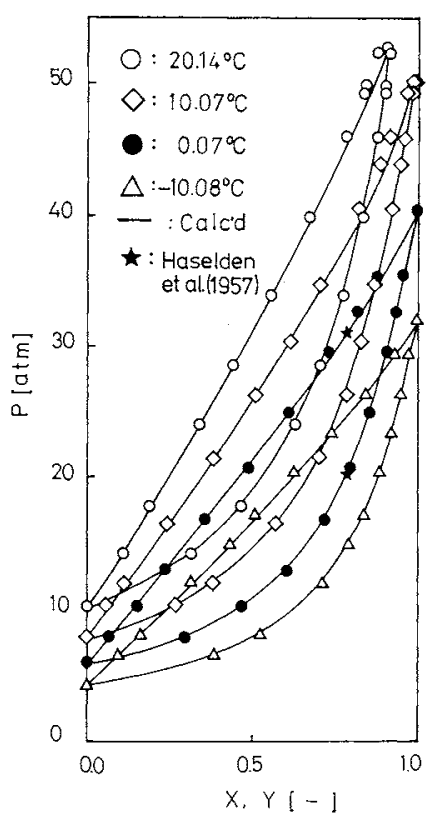

Fig. 5 Pressure-composition diagram for the system $\mathrm{C}_{2} \mathrm{H}_{4}(\mathbf{1})-\mathrm{C}_{3} \mathrm{H}_{6}(2)$

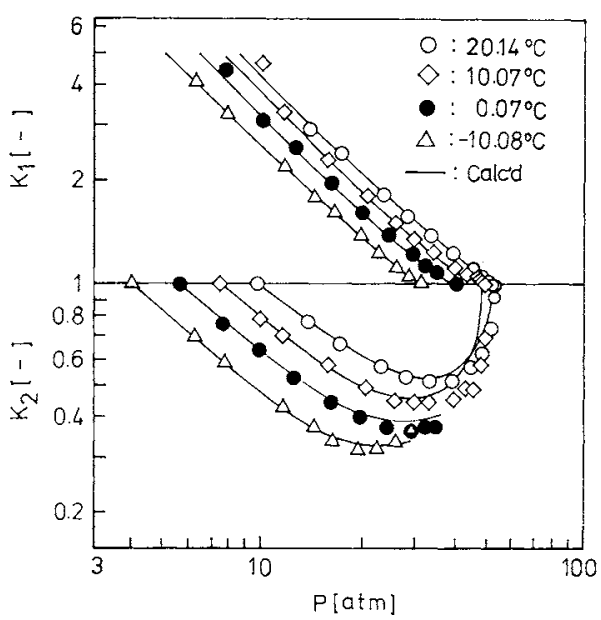

Fig. 7 Equilibrium constant vs. pressure for the system $\mathrm{C}_{2} \mathrm{H}_{4}(\mathbf{1})-\mathrm{C}_{3} \mathrm{H}_{6}(2)$

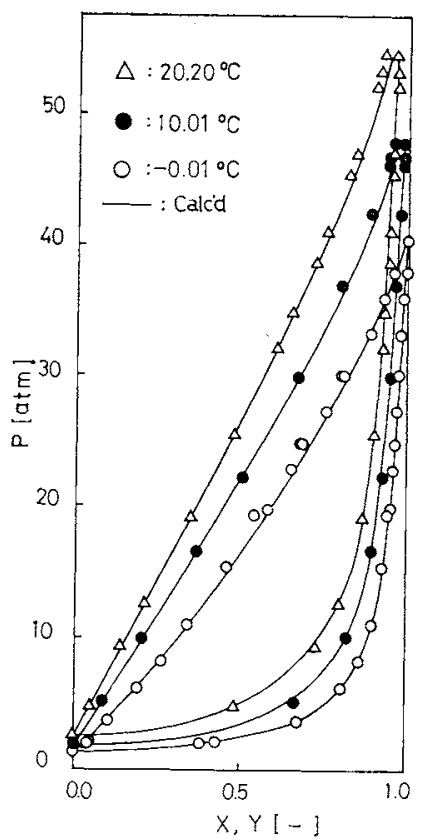

Fig. 6 Pressure-composition diagram for the system $\mathrm{C}_{2} \mathrm{H}_{4}(1)-1-\mathrm{C}_{4} \mathrm{H}_{8}(2)$

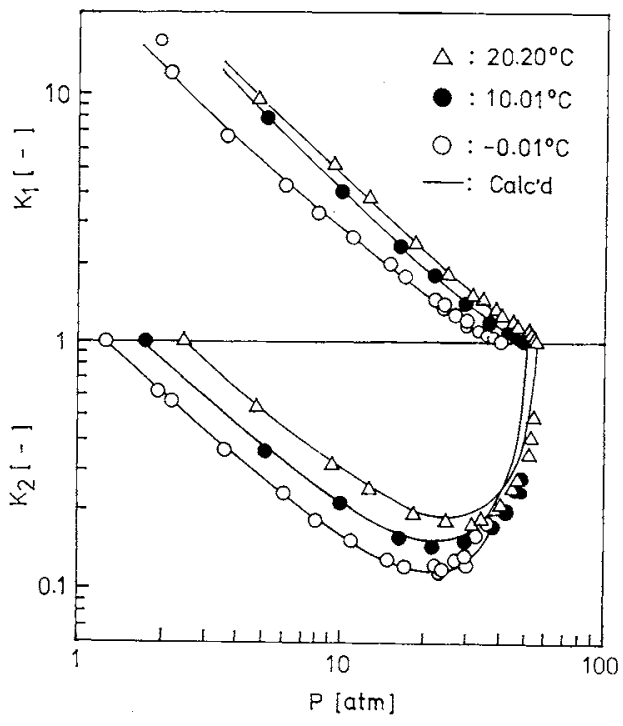

Fig. 8 Equilibrium constant vs. pressure for the system $\mathrm{C}_{2} \mathrm{H}_{4}(\mathbf{1})-\mathbf{1}-\mathrm{C}_{4} \mathrm{H}_{8}(2)$

Table 3 Mean deviation between observed and calculated vapor composition or pressure and interaction parameter

\begin{tabular}{|c|c|c|c|c|c|c|c|c|c|c|c|}
\hline System & $\begin{array}{c}\text { Temp. } \\
{\left[{ }^{\circ} \mathrm{C}\right]}\end{array}$ & 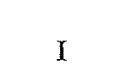 & $\begin{array}{l}\theta_{i j} \\
\text { II }\end{array}$ & III & $I$ & $\underset{\text { II }}{\Delta y_{1}[-]}$ & III & I & $P \underset{\mathrm{II}}{[\mathrm{atm}]}$ & III & $\begin{array}{l}\text { No. of } \\
\text { Data }\end{array}$ \\
\hline $\begin{array}{l}\text { Ethylene (1)- } \\
\text { Propylene (2) }\end{array}$ & $\begin{array}{r}-10.08 \\
0.07 \\
10.07 \\
20.14\end{array}$ & $\begin{array}{l}0.011 \\
0.016 \\
0.005 \\
0.005\end{array}$ & $\begin{array}{l}0.003 \\
0.013 \\
0.010 \\
0.007\end{array}$ & $\begin{array}{l}0.010 \\
0.017 \\
0.013 \\
0.010\end{array}$ & $\begin{array}{l}0.0018 \\
0.0048 \\
0.0087 \\
0.0037\end{array}$ & $\begin{array}{l}0.0054 \\
0.0091 \\
0.0121 \\
0.0067\end{array}$ & $\begin{array}{l}0.0050 \\
0.0097 \\
0.0124 \\
0.0074\end{array}$ & $\begin{array}{l}0.11 \\
0.20 \\
0.67 \\
0.67\end{array}$ & $\begin{array}{l}0.14 \\
0.18 \\
0.64 \\
0.53\end{array}$ & $\begin{array}{l}0.11 \\
0.21 \\
0.66 \\
0.47\end{array}$ & $\begin{array}{l}11 \\
11 \\
13 \\
12\end{array}$ \\
\hline $\begin{array}{l}\text { Ethylene (1)- } \\
\text { 1-Butene (2) }\end{array}$ & $\begin{array}{r}-0.01 \\
10.01 \\
20.20\end{array}$ & $\begin{array}{r}-0.021 \\
0.007 \\
0.014\end{array}$ & $\begin{array}{r}-0.023 \\
0.017 \\
0.021\end{array}$ & $\begin{array}{r}-0.016 \\
0.019 \\
0.024\end{array}$ & $\begin{array}{l}0.0010 \\
0.0047 \\
0.0053\end{array}$ & $\begin{array}{l}0.0009 \\
0.0053 \\
0.0070\end{array}$ & $\begin{array}{l}0.0008 \\
0.0064 \\
0.0085\end{array}$ & $\begin{array}{l}0.31 \\
0.62 \\
0.69\end{array}$ & $\begin{array}{l}0.31 \\
0.62 \\
0.58\end{array}$ & $\begin{array}{l}0.34 \\
0.62 \\
0.56\end{array}$ & $\begin{array}{l}20 \\
11 \\
15\end{array}$ \\
\hline
\end{tabular}

I, II and III: Modified Redlich-Kwong equation of Joffe et al., Soave and Peng, and Robinson respectively. $\Delta f=\sum_{i=1}^{N}\left|f_{\text {exp1 }}-f_{\text {cale }}\right| / N: N=$ No. of data 


\begin{tabular}{|c|c|c|c|c|}
\hline & $\begin{array}{r}\mathrm{C}_{2} \mathrm{H}_{4} \\
10.07^{\circ} \mathrm{C}\end{array}$ & $20.14^{\circ} \mathrm{C}$ & $\begin{array}{r}\mathrm{C}_{2} \mathrm{H}_{4}- \\
10.01^{\circ} \mathrm{C}\end{array}$ & $\begin{array}{l}-\mathrm{C}_{4} \mathrm{H}_{8} \\
20.20^{\circ} \mathrm{C}\end{array}$ \\
\hline $\begin{array}{l}\text { Composition (mole } \\
\text { fraction of ethylene) }\end{array}$ & 0.992 & 0.913 & 0.988 & 0.955 \\
\hline Pressure [atm] & 50.8 & 53.5 & 49.8 & 55.3 \\
\hline
\end{tabular}

usefulness of the new apparatus.

The data obtained are correlated with the aid of three two-parameter equations of state. Estimations of pressure and vapor composition are successfully made with the aid of interaction parameters, although somewhat large differences among them are found near the region of the critical point.

For some isotherms, the critical properties of two binary systems are presented in a limited range of composition.

\section{Appendix}

1. Modified Redlich-Kwong equation by Joffe et al. . $^{4)}$

$$
P=\underset{v-b_{i}}{R T}-\frac{a_{i i}}{T^{0.5} v\left(v+\bar{b}_{i}\right)}
$$

where

$$
\begin{aligned}
& a_{i i}=\Omega_{a_{i i}} R^{2} T c_{i}{ }^{2.5} / P c_{i} \\
& b_{i}=\Omega_{b_{i}} R T c_{i} / P c_{i}
\end{aligned}
$$

2. Modified Redlich-Kwong equation by Soave ${ }^{12)}$

$$
P=\underset{v-b_{i}}{R T}-\frac{a_{i i}\left(T r_{i}, \omega_{i}\right)}{v\left(v+b_{i}\right)}
$$

where

$$
\begin{aligned}
& a_{i i}\left(\operatorname{Tr}_{i}, \omega_{i}\right)=a\left(T c_{i}\right) \cdot \alpha_{i} \\
& a\left(T c_{i}\right)=0.427478 R^{2} T c_{i}{ }^{2} / P c_{i} \\
& \alpha_{i}{ }^{0.5}=1+S_{i}\left(1-T r_{i}{ }^{0.5}\right) \\
& S_{i}=0.480+1.574 \omega_{i}-0.176 \omega_{i}{ }^{2} \\
& b_{i}=0.08664 R T c_{i} / P c_{i}
\end{aligned}
$$

3. Peng and Robinson equation of state $\mathrm{e}^{10)}$

$$
P=\begin{array}{r}
R T \\
v-b_{i}
\end{array}-\frac{a_{i i}\left(T r_{i}, \omega_{i}\right)}{v(v+b)+b_{i}\left(v-b_{i}\right)}
$$

where

$$
\begin{aligned}
& a_{i i}\left(T r_{i}, \omega_{i}\right)=\alpha\left(T c_{i}\right) \cdot \alpha_{i} \\
& a\left(T c_{i}\right)=0.45724 R^{2} T c_{i}{ }^{2} / P c_{i} \\
& \alpha_{i}^{0.5}=1+m_{i}\left(1-T r_{i}{ }^{0.5}\right) \\
& m_{i}=0.37464+1.54226 \omega_{i}-0.26992 \omega_{i}{ }^{2} \\
& b_{i}=0.07780 R T c_{i} / P c_{i}
\end{aligned}
$$

4. Mixing rule for mixture

$$
a=\sum_{i} \sum_{j} x_{i} x_{j} a_{i j}
$$

$$
b=\sum_{i} x_{i} b_{i}
$$

where

$$
a_{i j}=\left(1-0_{i j}\right)\left(a_{i i} a_{j j}\right)^{0.5}
$$

\section{Acknowledgment}

The authors gratefully acknowledge the experimental assistance of Messrs. M. Yasuoka, M. Watanabe, Y. Araga and Y. Kakutani. The financial support was provided by Grant-inAid for Scientific Research of the Ministry of Education, Science and Culture, Japan.

Nomenclature

$$
\begin{array}{llr}
K & =\text { equilibrium constant } & {[-]} \\
P & =\text { total pressure } & {[\mathrm{atm}]} \\
P_{2^{s}} & =\text { saturated vapor pressure of } & \\
T & =\text { component 2 } & {[\mathrm{atm}]} \\
T c & =\text { critical temperature } & {[\mathrm{K}]} \\
T r & =\text { reduced temperature }(=T / T c) & {[\mathrm{K}]} \\
y & =\text { molar volume } & {[-]} \\
x & =\text { mole fraction in liquid phase } & {\left[\mathrm{cm}^{3} / \mathrm{g}-\mathrm{mol}\right]} \\
y & =\text { mole fraction in vapor phase } & {[-]} \\
\theta_{i j} & =\text { interaction parameter between } & {[-]} \\
\Omega_{a_{i i}, \Omega_{b_{i}}}= & \text { characteristic parameter of pure } \\
\omega_{1} & & \text { component } i
\end{array}
$$

\section{Literature Cited}

1) Fredenslund, Aa., J. Mollerup and L. J. Christiansen: Cryogenics, 13, 414 (1973).

2) Haselden, G. G., F. A. Holland, M. B. King and R. F. Strickland-Constable: Proc. Roy. Soc. London, Ser. A, 240, 1 (1957).

3) Hirata, M., S. Ohe and K. Nagahama: "Computer Aided Data Book of Vapor-Liquid Equilibria", Kodansha, Tokyo (1975).

4) Joffe, J., G. M. Schroeder and D. Zudkevitch: AIChE J., 16, 496 (1970).

5) Muirbrook, N. K. and J. M. Prausnitz: ibid., 11, 1092 (1965).

6) Nagahama, K.: Kagaku Kögaku, 42, 607 (1978).

7) Nagahama, K., H. Konishi, D. Hoshino and M. Hirata: J. Chem. Eng. Japan, 7, 323 (1974).

8) Ng, H.-J. and D. B. Robinson: J. Chem. Eng. Data, 23, 325 (1978).

9) Oellrich, L., U. Plöcker, J. M. Prausnitz and H. Knapp: Chem.-Ing.-Tech., 49, 955 (1977).

10) Peng, D.-Y. and D. B. Robinson: Ind. Eng. Chem., Fundam., 15, 59 (1976).

11) Slocum, E. W.: ibid., 14, 126 (1975).

12) Soave, G.: Chem. Eng. Sci., 27, 1197 (1972).

13) Zudkevitch, D. and J. Joffe: AIChE J., 16, 112 (1970). 